\title{
PENERAPAN PRINSIP RESTORATIVE JUSTICE MELALUI DISKRESI TERHADAP PELAKU ANAK PADA KEPOLISIAN RESORT TEGAL \\ Yunia Elly Masruroh yuniaellymasruroh@gmail.com
}

\begin{abstract}
The application of the principles of Restorative J ustice in the case of children in the Indonesian National Police can be implemented with a choice of two (2) types of action, namely diversion, and discretion. This study aims to analyze the role of the National Police in the application of the principles of Restorative Justice on criminal acts committed by children and to analyze constraints POLRES Tegal Restorative J ustice in the application of the principle of the offenses committed by children. The method used is the juridical sociological conducted by interviewing respondents, an inventory and study the legislation, as well as the study of literature. In the juvenile justice system, Tegal Police action in the application of the principles of Restorative J ustice through the discretion of the offenses committed by children in various legislations.
\end{abstract}

Keywords :Restorative J usticePrincipal, The Role of the Police Department, Police Discretion, J uvenile J ustice System.

\begin{abstract}
Abstrak
Penerapan prinsip Restorative Justicepada perkara anak di Kepolisian Republik Indonesia dapat dilaksanakan dengan pilihan 2 (dua) jenis tindakan, yaitu diversi dan diskresi. Penelitian ini bertujuan untuk menganalisis peran POLRI dalam penerapan prinsip Restorative Justice terhadap tindak pidana yang dilakukan oleh anak dan untuk menganalisis hambatan POLRES Tegal dalam penerapan prinsip Restorative Justice terhadap tindak pidana yang dilakukan oleh anak. Metode penelitian yang digunakan adalah yuridis sosiologis yang dilakukan dengan cara wawancara responden, menginventarisir dan mempelajari peraturan perundang-undangan, serta studi kepustakaan. Dalam sistem peradilan pidana anak, tindakan Polres Tegal dalam penerapan prinsip Restorative Justice melalui diskresi terhadap tindak pidana yang dilakukan oleh anak dalam berbagai peraturan perundang-undangan. Terdapat hambatan yang dialami POLRES Tegal dalam penerapan prinsip Restorative J ustice melalui diskresi terhadap tindak pidana yang dilakukan oleh anak.
\end{abstract}

Kata kunci : PrinsipRestorative J ustice, Kewenangan Kepolisian, Diskresi Kepolisian, Sistem Peradilan Pidana Anak.

Pendahuluan

Negara Kesatuan Republik

Indonesia adalah negara kepulauan

yang terdiri atas ribuan pulau yang

tersebar di seluruh wilayah

Nusantara.Keadaan geografis dan

jumlah penduduk Indonesia yang

sedemikian besarnya membuat

kemungkinan timbulnya tindak pidana

semakin tinggi.Ini menjadi konsekuensi

logis atas pengelolaan Sumber Daya
Alam yang tidak seimbang dan pembangunan di segala bidang yang tidak merata di masing-masing daerah.Kebutuhan hidup semakin tinggi, sedangkan pendapatan masing-masing individu menengah ke bawah tidak turut serta bertambah. Di sisi lain ada beberapa masyarakat kelas atas yang dengan mudah dapat memenuhi kebutuhan hidupnya. Kesenjangan hidup yang demikian di dalam 
403 | J urnal Idea Hukum

Vol. 2 No. 2 Oktober 2016

Magister Hukum Fakultas Hukum Universitas J enderal Soedirman

masyarakat merupakan salah satu faktor semakin meningkatnya kejahatan.

Padaperkembangannya,

kejahatan tidak hanya dilakukan oleh orang dewasa melainkan oleh anak. Pergaulan bebas yang negatif dan hedonis membuat anak cenderung melakukan cara pintas yang dianggap mudah untuk melakukan apa yang diinginkan tanpa campur tangan orang tua dan bertindak mengabaikan peraturan perundang-undangan yang berlaku.

Berdasarkan Sistem Database Pemasyarakatan, pada Bulan Februari 2016 terdapat 1.429 narapidana anak berada di tahanan dan Lapas seluruh wilayah Jawa Tengah. Dan terdapat 15.857 narapidana anak berada di tahanan dan Lapas seluruh Indonesia, 6.343 ditempatkan pada Lapas Anak dan dalam bimbingan BAPAS, kemudian sisanya sebanyak 9.514 ditempatkan di Lapas dewasa. ${ }^{1}$

Prinsip Restorative J usticedapat diterapkan pada tahap penyidikan di tingkat Kepolisian, hingga peradilan tingkat terakhir. Peneliti membatasi penelitian pada penyidikan di tingkat Kepolisian.Ada satu hal yang menarik untuk dianalisis mengenai posisi POLRI.POLRI diberikan kewenangan untuk melakukan tindakan lain berdasarkan penilaian sendiri sesuai dengan syarat dan ketentuan yang berlaku pada Undang-Undang Nomor 2 Tahun 2002 tentang Kepolisian Republik

1 http://smslap.ditjenpas.go.iddiakses pada 1 Maret 2016 pukul 15.45 WIB.
Indonesia yang lebih lanjut disebut dengan diskresi.

Penerapan prinsip Restorative Justice pada tindak pidana anak dapat dilaksanakan dengan pilihan 2 (dua) jenis tindakan, yaitu diversi dan diskresi. Diversi adalah bentuk penerapan prinsip Restorative Justice yang sudah dinormakan ke dalam Undang-Undang Sistem Peradilan Pidana Anak dan wajib diupayakan oleh aparat penegak hukum baik di tingkat penyidikan, penuntutan, maupun pemeriksaan di tingkat persidangan dengan syarat ancaman pidana yang dikenakan terhadap pelaku anak tidak lebih dari 7 (tujuh) tahun dan bukan pengulangan tindak pidana. Kemudian timbul permasalahan, bagaimana penyelesaiannya apabila para pihak sudah sepakat untuk menyelesaikan tindak pidana yang ancaman pidananya 7 (tujuh) tahun ke atas dengan jalur damai sementara Undang-Undang Sistem Peradilan Pidana Anak mengharuskan tindak pidana untuk dilanjutkan ke tingkat persidangan.

Pada prinsipnya, Restorative Justicemerupakan ide pembaharuan hukum pidana yang menghendaki pemulihan bagi pelaku maupun korban yang tidak hanya dilaksanakan melalui diversi. Sebagaimana telah dijelaskan sebelumnya bahwa penerapan prinsip Restorative Justice di Kepolisian Republik Indonesia mendasarkan pula pada pada ketentuan Pasal 16 ayat (1) huruf I j.o. Pasal 18 Undang-Undang Nomor 2 Tahun 2002 tentang Kepolisian 
atau biasa disebut sebagai diskresi. Tindakan diskresi seringkali berbenturan dengan aturan normatif yang mengharuskan anak dihadapkan pada peradilan.POLRES Tegal pernah menghadapi kasus demikian.Tindak pidana tersebut berhasil diselesaikan dengan jalan damai dan dimintakan penetapan diversi, akantetapi Pengadilan Negeri Slawi tidak mengabulkan permohonan penetapan diversi. Demi kepentingan anak, akhirnya Penyidik POLRI sebagai inisiator mengambil tindakan lain atau diskresi.

Berdasarkan hal tersebut di atas, penulis tertarik untuk membuat tesis yang menitikberatkan kepada peran POLRI sebagai pelaksana prinsip Restorative Justicedengan judul “PENERAPAN PRINSIP RESTORATIVE JUSTICE MELALUI DIKRESI TERHADAP PELAKU ANAK PADA KEPOLISIAN RESORT TEGAL".

\section{Perumusan Masalah}

Berdasarkan latar belakang yang telah diuraikan di atas, maka dapat diambil suatu permasalahan, yaitu :

1. Apakah dasar pertimbangan Polres Tegal dalam menerapkan prinsip Restorative Justice melalui diskresi terhadap tindak pidana yang dilakukan oleh anak?

2. Apakah yang menjadi hambatan POLRES Tegal dalam penerapan prinsip Restorative Justice melalui diskresi terhadap tindak pidana yang dilakukan oleh anak?

\section{Metode Penelitian}

Penelitian ini menggunakan metode kualitatif dengan pendekatan yuridis Sosiologis.Mempergunakan metode kualitatif mengingat dari permasalahan yang ada hendak mencari makna yang dalam dan rinci terhadap fenomena yang diteliti. ${ }^{2}$ Spesifikasi penelitian ini bersifat deskriptis sesuai dengan masalah dan tujuan dalam penelitian ini.Deskriptif dalam hal ini artinya memberikan gambaran tentang fenomena sosial yang ada dilakukan sesuai dengan metode peneleitian.

Penelitian ini berlokasi di Kantor Kepolisian Resort Tegal;Pos BAPAS Slawi dan Pengadilan Negeri Slawi.Informan penelitian yang menjadi sumber data adalah Penyidik anak pada Unit Pelayanan Perempuan dan Anak (PPA); Pelaku Anak; Pos BAPAS Slawi dan Pengadilan Negeri Slawi. Sumber data dari penelitian ini adalah data sekunder yang berupa KUHP, KUHAP, Undang-Undang Nomor 2 Tahun 2002 tentang Kepolisian Republik Indonesia, Undang-Undang Nomor 11 Tahun 2012 tentang Sistem Peradilan Pidana Anak, Peraturan Pemerintah Nomor 65 Tahun 2015 tentang Pedoman Pelaksanaan Diversi Dan Penanganan Anak Yang Belum Berumur 12 (Dua Belas) Tahun,

\footnotetext{
Sanapiah Faisal. 1990. Penelitian Kualitatif, Dasar-dasar Aplikasi. Malang : YA 3. HIm. 22.
} 
405 | J urnal Idea Hukum

Vol. 2 No. 2 Oktober 2016

Magister Hukum Fakultas Hukum Universitas J enderal Soedirman

dokumen resmi, dan buku-buku literatur yang berhubungan dengan obyek penelitian.

Dan data primer yang diperoleh secara langsung dari objek penelitian yang berupa keterangan-keterangan hasil wawancara dengan pihak PPA POLRES Tegal, Pelaku Anak, Petugas Pos Bapas Slawi dan Pengadilan Negeri Slawi terkait dengan masalah yang diteliti di lingkungan Kepolisian Resort Tegal sebagai pelengkap data sekunder. Metode penyajian data dalam penelitian ini akan disajikan dalam bentuk uraian yang disusun secara sistematis, logis, dan rasional. Metode analisis data dilakukan secara kualitatif.Metode pengumpulan data pada data primer yakni dengan cara wawancara kepada para responden, sedangkan pengumpulan data sekunder dilakukan dengan cara menginventarisir dan mempelajari peraturan perundangundangan. Data yang diteliti disampaikan dalam bentuk uraian secara deskriptis-sistematis.Analisis data dalam penelitian ini menggunakan analisa kualitatif dengan cara berpikir deduktif yang terdiri dari premis mayor, premis minor, dan kesimpulan.

\section{Pembahasan}

1. Dasar Pertimbangan Polres Tegal
Dalam Menerapkan Prinsip
Restorative Justice $\quad$ Melalui
Diskresi Terhadap Tindak Pidana
Yang Dilakukan Oleh Anak.

Berdasarkan hasil wawancara dengan para narasumber, Kepolisian Resort Tegal dalam menerapkan prinsip Restorative J usticemelalui diskresi pada pelaku anak selalu diupayakan. Penerapan prinsip Restorative Justicedapat dimanifestasikan ke dalam berbagai bentuk. Bentuk pertama, dari penerapan Prinsip Restorative Justice berdasarkan hasil penelitian adalah dengan dibuatkan surat perdamaian pidana atau penal consent berdasarkan kesepakatan para pihak pada tindak pidana persetubuhan anak. Khusus perkara yang pernah Polres Tegal tangani dengan diskresi, Penyidik Anak mempertimbangkan keberadaan korban persetubuhan anak yang mengakibatkan kehamilan. Apabila tindakan pelaku bukan merupakan pengulangan tindak pidana, maka segera diupayakan proses perdamaian dengan menghadirkan orang tua kedua belah pihak dan tokoh masyarakat di Kantor Kepolisian Resort Tegal. Dalam hal ini, Penyidik Anak bertindak sebagai inisiator dan fasilitator.

Bentuk kedua dari Penerapan prinsip Restorative Justice melalui diskresi berdasarkan hasil penelitian adalah diskresi dilakukan di tahap penyelidikan sebelum diterbitkan SPDP (Surat Pemberitahuan Dimulainya Penyidikan). Pada tahap lidik terhadap perkara anak, Polisi memandang perlu dilakukan diskresi 
ketika diversi tidak dapat menjadi solusi.

Bentuk ketiga dari Penerapan prinsip Restorative Justice melalui diskresi berdasarkan hasil penelitian adalah tidak dilakukan penahanan atas diri pelaku anak. Penyelesaian perkara melalui diskresi dilakukan Polres Tegal tanpa menahan pelaku anak karena pertimbangan status pelajar pelaku anak agar tetap dapat bersekolah.Pelaku tetap dapat menyelesaikan perkara melalui upaya damai yang dilakukan Kepolisian Resort Tegal setelah pulang sekolah.Pada prinsipnya Polres Tegal selalu mengupayakan tindakan terbaik bagi kepentingan pelaku anak maupun korban.Polres Tegal memahami keadilan masyarakat dan kepentingan anak menjadi hal yang prioritas. Sehingga meskipun kasus dilanjutkan, pelaku anak tetap dapat terlindungi dengan tidak dilakukan penahanan terhadap yang bersangkutan.

Penerapan prinsip Restorative Justice melalui diskresi di Kepolisian Resort Tegal memiliki dasar pertimbangan yang terdiri atas pertimbangan yuridis sebagai dasar kewenangan dan pertimbangan sosiologis sebagai wujud keadilan.

a. PertimbanganYuridis;

Landasan yuridis yang dijadikan dasar pertimbangan diskresi oleh Kepolisian Resort Tegal adalah sebagai berikut : b. Undang-Undang Nomor 8 Tahun 1981 Tentang KUHAP Dalam ketentuan Pasal 6 ayat (1) Undang-Undang Nomor 8 Tahun 1981 Tentang Kitab Undang-Undang Hukum Acara Pidana mengatur pengertian seorang penyelidik dan penyidik yang menurut Undang-Undang berhak untuk melakukan suatu tindakan penyidikan pada suatu tindak pidana pidana. Berikut adalah ketentuan Pasal 6 KUHAP :

Pasal 6

(1) Penyidik adalah :

a. pejabat polisi negara Republik Indonesia;

b. pejabat pegawai negeri sipil tertentu yang diberi wewenang khusus akan diatur lebih lanjut dalam peraturan pemerintah.

Pasal tersebut menentukan pemberian wewenang kepada setiap petugas atau pejabat Kepolisian sesuai dengan ruang lingkup kewenangan jabatan selaku aparat Kepolisian yang memiliki kualifikasi untuk menyidik suatu tindak pidana pidana dalam proses peradilan. Selanjutnya kewajiban dari Penyidik berdasarkan Pasal 6 ditegaskan oleh Pasal 7 KUHAP yang merupakan pedoman dalam melakukan suatu tindakan penyelidikan atau penyidikan 
407 | J urnal Idea Hukum

Vol. 2 No. 2 Oktober 2016

Magister Hukum Fakultas Hukum Universitas J enderal Soedirman

dengan tetap merujuk pada

Keputusan Kapolri Nomor 14

Tahun $2012 \quad$ Tentang

Manajemen Penyidikan Tindak

Pidana. Diantara bunyi Pasal

tersebut adalah:

Pasal 7

1) Penyidik sebagaimana dimaksud dalam Pasal 6 ayat

(1) huruf a karena kewajibannya mempunyai wewenang :

a. menerima-laporan atau pengaduan dari seorang tentang adanya tindak pidana;

b. melakukan tindakan pertama pada saat di tempat kejadian;

c. menyuruh berhenti seorang tersangka dan memeriksa tanda pengenal diri tersangka ;

d. melakukan penangkapan, penahanan, penggeledahan dan penyitaan;

e. melakukan pemeriksaan dan penyitaan surat;

f. mengambil sidik jari dan memotret seorang;

g. memanggil orang untuk didengar dan diperiksa sebagai tersangka atau saksi;

h. mendatangkan orang ahli yang diperlukan dalam hubungannya dengan pemeriksaan tindak pidana;

i. mengadakan penghentian penyidikan; j. mengadakan tindakan lain menurut hukum yang bertanggung jawab.

Ketentuan yang terdapat dalam Pasal 7 ayat (1) huruf $\mathrm{j}$ menjelaskan tentang kewajiban mengadakan tindakan lain menurut hukum yang bertanggung jawab. Mengingat wewenang Kepolisian untuk melakukan tindakan-tindakan Kepolisian tidak mungkin diatur secara limitatif (bersifat membatasi), maka di dalam ketentuan Pasal 7 ayat (1) huruf j dinyatakan bahwa "penyidik sebagaimana dimaksud dalam Pasal 6 ayat (1) karena kewajibannya mempunyai wewenang mengadakan tindakan lain menurut hukum yang bertanggung jawab", ketentuan tersebut merupakan landasan yuridis tindakan diskresi penyidik dalam penegakan hukum pidana sub penyidikan Sistem Peradilan Pidana (Criminal Justice System).

c. Undang-Undang Nomor 2 Tahun 2002 Tentang Kepolisian Negara Republik Indonesia.

Diskresi Kepolisian merupakan tindakan legal yang mana diatur didalam ketentuan Pasal 16 ayat (1) huruf I, dan ayat (2), kemudian dipertegas dalam Pasal 18 ayat (1) dan (2) 
UU Kepolisian RI sebagai berikut :

Pasal 16

(1)

Dalam rangka
menyelenggarakan
sebagaimana dimaksud dalam
Pasal 13 dan 14 di bidang
proses pidana, Kepolisian
Negara Republik Indonesia
berwenang untuk:

a. melakukan penangkapan,

penahanan,

penggeledahan, dan

penyitaan;

b. melarang setiap orang meninggalkan atau

memasuki tempat kejadian

tindak pidana untuk

kepentingan penyidikan;

c. membawa

dan

menghadapkan orang

kepada penyidik dalam

rangka penyidikan;

d. menyuruh berhenti orang

yang dicurigai dan

menanyakan serta

memeriksa tanda pengenal

diri;

e. melakukan pemeriksaan dan penyitaan surat;

f. memanggil orang untuk didengar dan diperiksa sebagai tersangka atau saksi;

g. mendatangkan orang ahli yang diperlukan dalam hubungannya dengan pemeriksaan tindak pidana; h. mengadakan penghentian penyidikan;

i. menyerahkan berkas tindak pidana kepada penuntut umum;

j. mengajukan permintaan secara langsung kepada pejabat imigrasi yang berwenang di tempat pemeriksaan imigrasi dalam keadaan mendesak atau mendadak untuk mencegah atau menangkal orang yang disangka melakukan tindak pidana;

k. memberi petunjuk dan bantuan penyidikan kepada penyidik pegawai negeri sipil sertanmenerima hasil penyidikan penyidik pegawai negeri sipil untuk diserahkan kepada penuntut umum; dan

I. mengadakan tindakan lain menurut hukum yang bertanggung jawab.

(2) Tindakan lain sebagaimana dimaksud dalam ayat (1) huruf I adalah tindakan penyelidikan dan penyidikan yang dilaksanakan jika memenuhi syarat sebagai berikut :

a. tidak bertentangan dengan suatu aturan hukum;

b. selaras dengan kewajiban hukum yang mengharuskan tindakan tersebut dilakukan; 
409 | J urnal Idea Hukum

Vol. 2 No. 2 Oktober 2016

Magister Hukum Fakultas Hukum Universitas J enderal Soedirman

c. harus patut, masuk akal, dan termasuk dalam lingkungan jabatannya;

d. pertimbangan yang layak berdasarkan keadaan yang memaksa; dan

e. menghormati hak asasi manusia.

Pasal 18

(1) Untuk kepentingan umum pejabat Kepolisian Negara Republik Indonesia dalam melaksanakan tugas dan wewenangnya dapat bertindak menurut penilaiannya sendiri;

(2) Pelaksanaan ketentuan sebagaimana dimaksud dalam ayat (1) hanya dapat dilakukan dalam keadaan yang sangat perlu dengan memperhatikan peraturan perundang-undangan, serta Kode Etik Profesi Kepolisian Negara Republik Indonesia.

Yang perlu dicermati dari ketentuan tersebut adalah diskresi boleh dilakukan asalkan memenuhi syarat yang sudah ditentukan oleh UU Kepolisian RI.Dari beberapa ketentuan tersebut tidak ada penjelasan mengenai batasan substansial untuk dapat diambil tindakan diskresi.Jadi Penyidik Polri diberikan keleluasaan untuk bertindak sesuai penilaiannya sendiri. Berbicara penerapan Prinsip Restorative Justice tidak terlepas dari fungsi Kepolisian dalam pelaksanaan tugas Kepolisian yakni pemeliharaan keamanan dan ketertiban masyarakat, penegakan hukum, perlindungan, pengayoman, dan pelayanan kepada masyarakat.

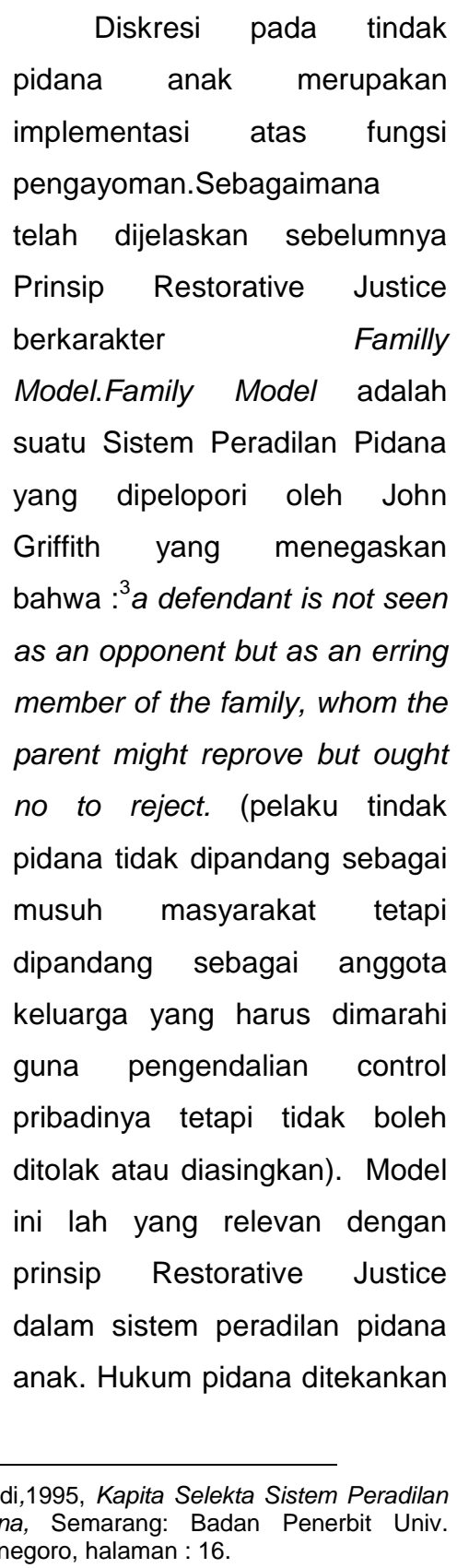
Diponegoro, halaman : 16. 


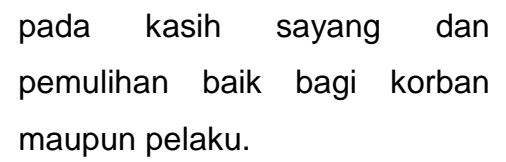

Menurut Pudi Rahardi diskresi yang diatur di dalam ketentuan Pasal 16 ayat (1) huruf I, dan ayat (2), yang dipertegas dalam Pasal 18 ayat (1) dan (2) UU Kepolisian RI merupakan sumber kewenangan yang bersumber dari asas kewajiban umum (plichtmatigheids beginsel) Kepolisian. Asas tersebut merupakan suatu asas yang memberikan kewenangan kepada pejabat Kepolisian untuk bertindak atau tidak bertindak menurut penilaiannya sendiri, dalam rangka kewajiban umumnya guna menjaga, memelihara ketertiban dan menjamin keamanan.

d. Yurisprudensi.

Yurisprudensi mengenai diskresi Kepolisian pada masa penjajahan yang terkenal adalah berdasarkan Arrest Hoge Raad tanggal 25 Januari 1892 dan tanggal 11 Maret 1914 yang antara lain mengatakan :

..... untuk sahnya segala tindakan-tindakan Kepolisian (Rechtmating) tidak selalu harus berdasarkan peraturan Undang-Undang (Wettelijk Voor Schrift).

\section{Hambatan Polres Tegal Dalam Menerapkan Prinsip Restorative Justice Melalui Diskresi Terhadap Tindak Pidana yang Dilakukan oleh} Anak.

Dalam kaitannya dengan faktor yang mempengaruhi penegakan hukum, L. M. Friedman memberikan penjelasan bahwa sistem hukum terdiri atas substansi hukum (aturan baik tertulis maupun tidak tertulis dalam sebuah sistem), struktur hukum (aparatur pembuat dan penegak hukum), kultur hukum (gagasan-gagasan, sikap-sikap, keyakinan-keyakinan,harapan-harapan dan pendapat tentang hukum). Hambatan penerapan Prinsip Restorative Justice melalui diskresi terhadap tindak pidana yang dilakukan oleh anak merupakan salah satu faktor yang mempengaruhi penegakan hukum.

Dalam hal penyelidikan dan penyidikan yang dilakukan oleh penyidik Anak Kepolisian, kewenangan diskresi yang dimiliki Polisi sebagai pejabat publik dalam hal penegakan hukum (Law Enforcement) seringkali dihadapkan dengan tindak pidana yang dirasa ringan, kurang efektif dan efisien untuk dilakukannya penyidikan sampai dilimpahkan (P21) ke Penuntut Umum Kejaksaan, selanjutnya ke tahap Pengadilan untuk diputus oleh Hakim. Hal yang demikian tidak terjadi di Kepolisian Resort Tegal khususnya Unit Pelayanan Perempuan dan Anak (PPA). Unit Pelayanan Perempuan dan Anak (PPA) selalu mengedepankan kepentingan terbaik baik anak dengan tetap memperhatikan korban dan saling berkoordinasi antar penyidik untuk menyamakan persepsi. Dalam hal pemeriksaan pada saat penyelidikan maupun penyidikan, penyelidik maupun penyidik seringkali menemui kendala dalam menerapkan Prinsip Restorative Justice melalui diskresi. Berikut Penulis 
411 | J urnal Idea Hukum

Vol. 2 No. 2 Oktober 2016

Magister Hukum Fakultas Hukum Universitas J enderal Soedirman

jabarkan hambatan penerapan

Restorative Justice melalui diskresi dengan mendasarkan pada teori Lawrence Meirs Friedman :

1. Substansi Hukum;

Substansi hukum diartikan sebagai seperangkat aturan baik tertulis maupun tidak tertulis dalam sebuah sistem. Substansi hukum yang merupakan hambatan pelaksanaan diskresi di Kepolisian Resort Tegal adalah Undang-Undang Sistem Peradilan Pidana Anak.

\subsection{Undang-Undang Sistem Peradilan}

Pidana Anak yang Multitafsir;

Hambatan penerapan diskresi terhadap penanganan tindak pidana tindak pidana anak, justru hadir dari Undang-Undang Sistem Peradilan Pidana Anak (UU SPPA) sendiri. Undang-Undang Sistem Peradilan Pidana Anak membatasi upaya perdamaian hanya pada ancaman pidana di bawah 7 (tujuh) tahun dan bukan merupakan pengulangan tindak pidana. Persepsi dari Penyidik Anak Kepolsian Resort Tegal, ketentuan tersebut merupakan kewajiban diversi untuk tindak pidana yang ancaman pidananya di bawah 7 (tujuh) tahun dan bukan merupakan pengulangan tindak pidana. Dan apabila terdapat tindak pidana dengan pelaku anak yang ancaman pidananya di atas 7 (tujuh) tahun dan bukan merupakan pengulangan tindak pidana, maka Penyidik Anak Kepolsian Resort Tegal menafsirkan ketentuan tersebut dengan tetap diperbolehkan dilakukan upaya damai, tetapi tidak wajib.

2.1. Belum ada kepastian hukum dari produk diskresi (penal consent);

Diskresi pada tindak pidana anak menghasilkan produk persetujuan pidana (penal consent). Pelaku dan keluarga pelaku diberikan pilihan untuk setuju atau tidak terhadap persetujuan pidana yang diajukan oleh pihak korban. Apabila setuju maka proses pemeriksaan tindak pidana dihentikan, apabila tidak setuju maka proses pemeriksaan tindak pidana ditingkatkan ke tingkat penyidikan hingga penuntutan dan vonis. Dengan catatan, penal consent adalah produk dari diskresi Kepolisian RI untuk menyelesaikan tindak pidana tindak pidana yang ancaman pidananya di atas 7 (tujuh) tahun dimana UU SPPA hanya mewajibkan diversi pada ancaman pidana di bawah 7 (tujuh). Produk diversi adalah penetapan diversi dari pengadilan. Penal consent dihasilkan dari proses mediasi penal yang difasilitasi oleh Kepolisian RI berdasarkan kewenangan diskresi.

Pada mediasi perdata, kesepakatan perdamaian yang dikuatkan dengan akta perdamaian akan memiliki kekuatan eksekutorial. Apabila upaya perdamaian berhasil, maka suatu tindak pidana perdata pun selesai penanganannya dan tidak dilanjutkan pada penyelesaian tindak pidana secara litigasi. Berbeda dengan penal consent yang dihasilkan dari mediasi penal dengan dasar diskresi. 
Tidak adanya suatu peraturan yang mengatur tata cara mediasi penal, maka berakibat pada tidak ada pula ketentuan yang tegas mengenai akibat hukum dari kesepakatan mediasi penal terhadap proses penanganan tindak pidana pidana.

2. Struktur Hukum (aparatur pembuat dan penegak hukum),

Pada aspek ini ada beberapa hal yang turut menjadi penghambat pelaksanaan diskresi adalah sebagai berikut :

2.1. Keorganisasian;

$\begin{array}{lr}\text { Instruksi dari } & \text { pimpinan } \\ \text { secara struktural } & \text { juga } \\ \text { keorganisasian } & \text { penting } \\ \text { mempunyai faktor } & \text { suatu } \\ \text { dalam pengambilan } & \text { sem } \\ \text { tindakan diskresi oleh penyidik } \\ \text { Kepolisian. Meskipun sifatnya } \\ \text { kasuistik, keinginan diskresi } \\ \text { dari penyidik harus diabaikan } \\ \text { dengan instruksi dari pimpinan } \\ \text { untuk memproses atau } \\ \text { melanjutkan penyidikan. }\end{array}$

3. Kultur Hukum (gagasan-gagasan, sikap-sikap, keyakinankeyakinan,harapan-harapan dan pendapat tentang hukum)

3.1. Keilmuan dari aparat penegak hukum tentang Restorative Justice;

Aparat petugas Kepolisian mempunyai tugas dan fungsi yang berbeda-beda, hal tersebut sesuai dengan kualifikasi pendidikan dan jabatannya yang diemban dalam rangka tugas Kepolisian. Peran dan kedudukan polisi sebagai seorang penyidik telah memberikan wewenang pada polisi tersebut untuk melakukan diskresi sesuai yang telah diatur oleh undangundang sehingga petugas penyidik tersebut dapat mempergunakan diskresi dalam melaksanakan tugasnya. Dari hasil penelitian Penulis, pengetahuan tentang tindakan diskresi oleh Polisi tidak merata di seluruh sumber daya manusia yang ada dilingkungan Sat Reskrim Polres Tegal. Tidak sedikit yang berpaham bahwa segala sesuatunya harus sesuai prosedur dan rigid sesuai undang-undang yang berlaku.

\subsection{Reaksi masyarakat}

Diskresi yang berkaitan dengan anak ini cukup dilematis. Sangat dimungkinkan untuk tindak pidana yang sama, dilakukan dengan proses penyelesaian yang berbeda. Selain pihak korban dan pelaku, reaksi masyarakat juga dipertimbangkan. Karena salah satu misi Kepolisian adalah memberikan perlindungan, pengayoman dan pelayanan secara mudah, responsif dan tidak diskriminatif. Kepolisian akan terlebih dulu mempertimbangkan apakah ketika diupayakan damai, masyarakat akan merasa resah terhadap kenakalan anak yang menjurus pada kejahatan atau tidak. Diskresi yang masih kasuistik ini kembali lagi disebabkan karena belum ada peraturan perundang-undangan yang secara khusus mengatur keberadaan diskresi, mekanisme, dan akibat hukumnya. 
413 | J urnal Idea Hukum

Vol. 2 No. 2 Oktober 2016

Magister Hukum Fakultas Hukum Universitas J enderal Soedirman

\subsection{Keinginan kuat dari}

pihak korban untuk tetap melanjutkan proses pemeriksaan terhadap pelaku.

Berdasarkan hasil penelitian, sebenarnya ada beberapa tindak pidana yang tindak pidana yang memungkinkan dilakukannya diskresi namun pihak korban tidak sepakan dan ingin tetap menuntut agar pelakunya dihukum. Korban masih berorientasi pada balas dendam atas tindakan pelaku terhadap dirinya.

\section{Penutup}

\section{Simpulan}

Berdasarkan hasil penelitian dan pembahasan yang telah diuraikan, maka dapat disimpulkan hal-hal sebagai berikut :

1. Dasar pertimbangan Polres Tegal dalam penerapan prinsip Restorative J ustice melalui diskresi terhadap tindak pidana yang dilakukan oleh anak terbagi atas pertimbangan yuridis dan sosiologis. Pertimbangan Polres Tegal dalam penerapan prinsip Restorative J ustice melalui diskresi terhadap tindak pidana yang dilakukan oleh anak adalah sebagai berikut:

a. Adanya kewenangan untuk mengadakan tindakan lain menurut hukum yang bertanggung jawab. Hal ini berdasarkan ketentuan Pasal 7 ayat (1) huruf j Kitab Undangundang Hukum Acara Pidana (KUHAP). b. Adanya kewenangan diskresi Kepolisian berdasarkan pasal Pasal 16 ayat (1) huruf I dan Pasal 18 ayat (1) UndangUndang Nomor 2 Tahun 2002 Tentang Kepolisian Negara Republik Indonesia.

c. Adanya Arrest Hoge Raad tanggal 25 Januari 1892 dan tanggal 11 Maret 1914 yang menyatakan "....... untuk sahnya segala tindakan-tindakan Kepolisian (Rechtmating) tidak selalu harus berdasarkan peraturan Undang-Undang (Wettelijk Voor Schrift).

d. Tindak pidana oleh anak tersebut merupakan (first offender);

e. Pelaku anak masih bersekolah;

f. Adanya kesepakatan untuk berdamai antara pelaku dan korban;

g. Adanya ganti rugi yang diberikan oleh pelaku kepada korban;

h. Tindak pidana yang dilakukan bukan tindak pidana yang mengakibatkan hilangnya nyawa, luka berat, atau cacat seumur hidup atau tindak pidana yang mengganggu/merugikan kepentingan umum;

2. Hambatan POLRES Tegal dalam penerapan prinsip Restorative Justice melalui diskresi terhadap tindak pidana yang dilakukan oleh anak adalah sebagai berikut : 
a. Substansi Hukum (seperangkat aturan baik tertulis maupun tidak tertulis dalam sebuah sistem) terdiri dari :

1) Undang-Undang Sistem Peradilan Pidana Anak yang menimbulkan missed communication atau perbedaan persepsi antar penegak hukum;

2) Belum ada kepastian hukum dari produk diskresi (penal consent);

b. Struktur Hukum (aparatur pembuat dan penegak hukum) berupa Keorganisasian yang masih kuat dimana anggota Kepolisian harus mematuhi instruksi dari pimpinan sesuai struktur organisasi Kepolisian RI untuk memproses atau melanjutkan penyidikan.

c. Kultur Hukum (gagasangagasan, sikap-sikap, keyakinan-keyakinan,harapanharapan dan pendapat tentang hukum) terdiri dari:

1) Keilmuan dari aparat penegak hukum terhadap Restorative J ustice;

2) Reaksi masyarakat yang merasa resah terhadap kenakalan anak yang menjurus pada kejahatan;

3) Keinginan kuat dari pihak korban untuk tetap melanjutkan proses pemeriksaan terhadap pelaku;
4) Tuntuan dari ganti rugi dari pihak korban yang terlalu tinggi terhadap pelaku.

\section{Saran}

Berdasarkan kesimpulan di atas, saran/rekomendasi yang dapat penulis ajukan dalam penelitian tesis ini adalah:

1. Perlu dipahami bagi aparat penegak hukum khususnya Polres Tegal mengenai penerapan prinsip Restorative J ustice melalui diskresi terhadap pelaku anak. Persepsi mengenai tidak ditahannya pelaku anak pada dasarnya termasuk dalam tindakan diskresi Kepolisian namun demikian prinsip perlibatan korban tidak terakomodir secara komprehensif sebagaimana prinsip Restorative J ustice.

2. Bagi Lembaga Legislatif dan Eksekutif diharapkan agar segera memformulasikan konsep diskresi berbasis keadilan restorative dalam bentuk peraturan perundangundangan sebagai landasan yuridis bagi para penegak hukum baik Kepolisian, Kejaksaan dan Pengadilan khususnya dalam penanganan tindak pidana tindak pidana dengan pelaku anak beserta mekanisme dan akibat hukumnya sehingga Aparat Kepolisian sebagai penegak hukum berkeyakinan atas diskresi yang dijalankan dan turut pula memberikan kepastian status hukum bagi Pelaku anak. 
415 | J urnal Idea Hukum

Vol. 2 No. 2 Oktober 2016

Magister Hukum Fakultas Hukum Universitas J enderal Soedirman

\section{Daftar Pustaka}

Faisal, Sanapiah. 1990. Penelitian

Kualitatif, Dasar-dasar Aplikasi.

Malang: YA3.

Muladi.1995.Kapita Selekta Sistem

Peradilan Pidana.Semarang:

Badan Penerbit Univ. Diponegoro.

http://smslap.ditjenpas.go.id 